\title{
Chaperone Hsp27 inhibits translation during heat shock by binding eIF4G and facilitating dissociation of cap-initiation complexes
}

\author{
Rafael Cuesta, Gaurav Laroia, and Robert J. Schneider ${ }^{1}$ \\ Department of Microbiology, New York University School of Medicine and Kaplan Cancer Center, New York, \\ New York 10016 USA
}

Inhibition of protein synthesis during heat shock limits accumulation of unfolded proteins that might damage eukaryotic cells. We demonstrate that chaperone Hsp27 is a heat shock-induced inhibitor of cellular protein synthesis. Translation of most mRNAs requires formation of a cap-binding initiation complex known as eIF4F, consisting of factors eIF4E, eIF4A, eIF4E kinase Mnk1, poly(A)-binding protein, and adaptor protein eIF4G. Hsp27 specifically bound eIF4G during heat shock, preventing assembly of the cap-initiation/eIF4F complex and trapping eIF4G in insoluble heat shock granules. eIF4G is a specific target of Hsp27, as eIF4E, eIF4A, Mnk1, poly(A)-binding protein, eIF4B, and eIF3 were not bound by Hsp27 and were not recruited into insoluble complexes. Dissociation of eIF4F was enhanced during heat shock by ectopic overexpression of Hsp25, the murine homolog of human Hsp27. Overexpression of Hsc70, a constitutive homolog of Hsp70, prevented loss of cap-initiation complexes and maintained eIF4G solubility. Purified Hsp27 specifically bound purified eIF4G in vitro, prevented in vitro translation, eliminated eIF4G interaction with protein binding factors, and promoted eIF4G insolubilization. These results therefore demonstrate that Hsp27 is a heat-induced inhibitor of eIF4F-dependent mRNA translation.

[Key Words: Heat shock; translation; eIF4G; chaperones; eIF4F]

Received February 4, 2000; revised version accepted May 1, 2000.

Mammalian cells respond to heat stress in a highly orchestrated manner. Heat shock activates a specific transcriptional response and largely inhibits protein synthesis, establishing conditions that favor the exclusive translation of heat shock mRNAs (for review, see Duncan 1996; Morimoto 1998). Translational inhibition of non-heat shock mRNAs during heat stress prevents synthesis of nascent proteins that might misfold because of elevated temperature and impair the cell (Morimoto 1998). mRNAs that are specifically translated in mammalian cells during heat shock generally encode molecular chaperones, such as heat shock proteins (Hsps) Hsp100, Hsp90, Hsp70, Hsp60, Hsp40, and Hsp27 (Morimoto 1998), which increase in abundance through preferential translation of their mRNAs. Heat shock chaperones facilitate native protein refolding and increase cell survival following thermal stress (Parsell and Lindquist 1993). In mammalian cells, the small Hsp family (Hsp25 in mouse, Hsp27 in human) are ATP-independent chaperones that physically complex with certain unfolding protein intermediates, limiting denaturation and en-

${ }^{1}$ Corresponding author.

E-MAIL schner01@popmail.med.nyu.edu; FAX (212) 263-8276. hancing thermoresistance of the cell (Jakob et al. 1993; Ehrnsperger et al. 1997). During recovery from heat shock, ATP-dependent chaperones Hsp40, Hsp60, Hsp70, and the Hsp100 family, participate in refolding protein intermediates (Craig et al. 1994; Glover and Lindquist 1998). Misfolded or excessively aggregated proteins are degraded by the ubiquitin-proteasome pathway, which is linked to the heat shock chaperone network (Morimoto 1998). Currently, only a few identified proteins have been shown to be specifically trapped by Hsp27.

The ability of the translation apparatus to withstand irreversible inactivation during heat stress is associated in an unknown way with expression of Hsp25/27 and Hsp70/Hsc70 proteins (Liu et al. 1992; Li et al. 1995; Carper et al. 1997; for review, see Duncan 1996). It is also generally thought that these chaperones protect the protein synthetic apparatus during translational inhibition induced by heat shock (Mizzen and Welch 1988; Liu et al. 1992; Carper et al. 1997). It is not well understood how heat shock blocks protein synthesis in mammalian cells. Heat shock induces dephosphorylation and possibly inactivation of cap-binding protein eIF4E, in a wide variety of cell types, leading to inhibition of cap-depen- 
dent mRNA translation (Duncan and Hershey 1989; Lamphear and Panniers 1990). eIF4E forms a cap-initiation complex with the RNA helicase eIF4A and eIF4G, collectively referred to as translation initiation factor eIF4F. eIF4G also binds poly(A)-binding protein (PABP). The cap-initiation complex unwinds 5 ' secondary structure (Sonenberg 1996), facilitating cap- and poly(A)-dependent mRNA translation (Imataka et al. 1998). Capdependent mRNA translation correlates with phosphorylation of eIF4E, which is carried out by the kinase Mnk1 (Fukunaga and Hunter 1997; Waskiewicz et al. 1997), a member of the cap-initiation complex. Mnk1 facilitates phosphorylation eIF4E in vivo when both are bound to eIF4G (Pyronnet et al. 1999; Waskiewicz et al. 1999). Inhibition of cap-dependent translation correlates with decreased phosphorylation of eIF4E, which occurs during heat shock and infection with certain viruses (Huang and Schneider 1991; Feigenblum and Schneider 1993, 1996; Feigenblum et al. 1998; Yueh and Schneider 1996, 2000).

A family of small eIF4E-binding proteins known as 4E-BP-1, 4E-BP-2, and 4E-BP-3 bind and sequester eIF4E in a phosphorylation-dependent manner (Lin et al. 1994; Pause et al. 1994; Haghighat et al. 1995; Beretta et al. 1996). Hypophosphorylated 4E-BP1 binds eIF4E during heat shock (Feigenblum and Schneider 1996; Vries et al. 1997; Wang et al. 1998). Studies indicate that although 4E-BP binding of eIF4E participates in inhibition of eIF4E phosphorylation and shutoff of protein synthesis during heat shock, it is not sufficient, and other uncharacterized components of the heat shock response have been implicated (Feigenblum and Schneider 1996; Vries et al. 1997; Wang et al. 1998).

Here we show that inhibition of eIF4F(cap)-dependent protein synthesis during heat shock involves Hsp27. Hsp27 was found to specifically bind eIF4G, which is coupled to dissociation of the eIF4F(cap)-complex and insolubilization of eIF4G into heat shock granules, consistent with inhibition of non-heat shock mRNA translation. These results define eIF4G as a physiological target of Hsp27, and they describe a novel molecular mechanism for inhibition of protein synthesis during heat shock.

\section{Results}

Heat shock does not impair Mnk1 kinase activity

The eIF4E kinase, Mnk1, is a member of the eIF4F complex, which facilitates phosphorylation of eIF4E and translation of eIF4F(cap)-dependent mRNAs (Pyronnet et al. 1999; Waskiewicz et al. 1999). Because inhibition of mRNA translation during heat shock is strongly associated with a block in eIF4E phosphorylation, we investigated whether the activity of Mnk1 or its interaction with eIF4G are targets for control of protein synthesis during heat shock. Studies first determined whether heat shock blocks eIF4F(cap)-dependent translation by blocking Mnk1 kinase activity. 293T cells were transfected with plasmids expressing GST-Mnk1, or a kinase-defec- tive mutant of Mnk1 (T2A2; Waskiewicz et al. 1997). Cells were maintained at $37^{\circ} \mathrm{C}$, or heat-shocked at $44^{\circ} \mathrm{C}$ for $2 \mathrm{hr}$, or treated with epidermal growth factor (EGF). GST-Mnk1 was isolated by glutathione-Sepharose chromatography and assayed for protein kinase activity by its ability to phosphorylate purified, recombinant eIF4E in an in vitro reaction using $\left[\gamma^{-32} \mathrm{P}\right]$ ATP (Fig. 1). Equal amounts of Mnk1 protein (wild type or T2A2 mutant) and recombinant eIF4E were used to assay Mnk1 kinase activity (Fig. 2, top and middle). Although in vivo Mnk1 preferentially phosphorylates eIF4E as part of a complex with eIF4G, in vitro Mnk1 phosphorylates eIF4E in the absence of eIF4G if higher concentrations of eIF4E are used. GST-Mnk1 purified from cells at $37^{\circ} \mathrm{C}$ strongly phosphorylated recombinant eIF4E, whereas the kinaseinactive Mnk1 mutant did not. Mnk1 purified from heatshocked cells consistently displayed only a small decrease in phosphorylation of $\sim 50 \%$. Treatment of cells with EGF, an activator of eIF4E phosphorylation (Feigenblum et al. 1998), increased Mnk1 kinase activity about threefold, demonstrating that kinase activity is responsive to regulation. These results demonstrate that heat shock does not significantly impair the kinase activity of Mnk1.

\section{Mnk1 is dissociated from eIF4G during heat shock}

Given that the kinase activity of Mnk1 is not strongly impaired by heat shock, we determined whether heat

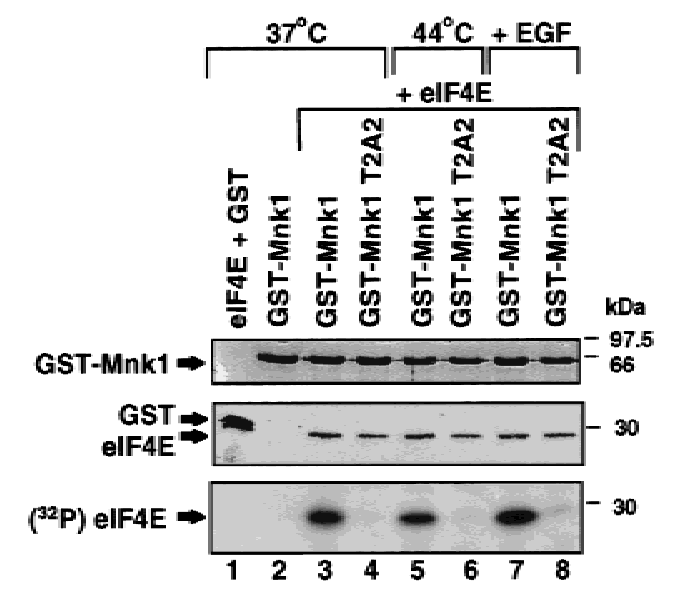

Figure 1. Heat shock does not significantly impair Mnk1 kinase activity. 293T cells were transfected with plasmids expressing GST-, GST-Mnk1, or GST-T2A2 (a kinase deficient mutant of Mnk1) (Waskiewicz et al. 1997). Cells were maintained at $37^{\circ} \mathrm{C}$ or heat-shocked at $44^{\circ} \mathrm{C}$ for $2 \mathrm{hr}$, or treated with $30 \mathrm{ng}$ of human EGF/ml for 15 min (Feigenblum et al. 1998). Equal amounts of GST proteins were recovered from cell lysates by glutathione-Sepharose chromatography and incubated with purified, recombinant (nonphosphorylated) eIF4E and $\left[\gamma^{-32} \mathrm{P}\right] \mathrm{ATP}$ in an in vitro kinase reaction. (Top, middle) Proteins resolved by SDS-PAGE and stained with Coomassie blue. (Bottom) Same gel visualized by autoradiography. Bands were quantitated by digital densitometry and are typical of at least three independent experiments. 
shock involves dissociation of Mnk1 from eIF4G, as this would in turn block eIF4E phosphorylation (a hallmark of heat shock) and inhibit eIF4F(cap)-dependent mRNA translation. 293T cells were transfected with GST- or GST-Mnk1 expression plasmids, then heat-shocked for $2 \mathrm{hr}$ at $44^{\circ} \mathrm{C}$, which is optimal for induction in these cells (Yueh and Schneider 1996; see Fig. 3C, below). GSTMnk1 was purified and examined for interaction with eIF4G and eIF4E by gel electrophoresis and immunoblotted with specific antisera. Heat shock did not alter the abundance of GST-Mnk1 protein (Fig. 2A, bottom). However, recovery of GST-Mnk1 protein by glutathione-Sepharose chromatography showed that its binding to eIF4G and eIF4E was reduced 20 -fold by heat shock (Fig. 2A, lanes 2,4). Decreased association of Mnk1 with the eIF4F complex during heat shock was associated with reduced phosphorylation of eIF4E, shown by impaired in vivo phosphorylation of eIF4E with ${ }^{32} \mathrm{PO}_{4}$, without a change in eIF4E abundance (Fig. 2C). Previous reports provided evidence consistent with inhibition of eIF4E phosphorylation during heat shock, rather than increased eIF4E phosphatase activity (e.g., Duncan et al. 1987; Lamphear and Panniers 1990, 1991; Feigenblum and Schneider 1996).

Next, it was determined whether sequestration of eIF4E by 4E-BP1, which is induced by heat shock, also disrupts the interaction of Mnk1 with eIF4F. Cells were transfected with GST-Mnk1 and subjected to heat shock, and the association of eIF4E with eIF4G or 4E-BP1 was examined. The interaction of eIF4E with eIF4G was

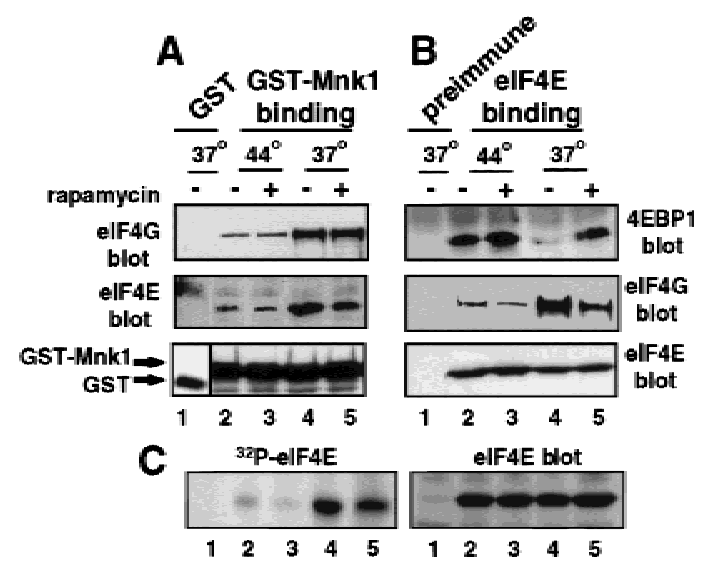

Figure 2. Heat shock blocks binding of Mnk1 to eIF4F. Cells were transiently transfected with plasmids expressing GST- or GST-Mnk1, then untreated, treated with $20 \mathrm{ng} / \mathrm{ml}$ of rapamycin for $2 \mathrm{hr}$, heat shocked at $44^{\circ} \mathrm{C}$ for $2 \mathrm{hr}$, or treated with rapamycin and heat-shocked simultaneously. Equal amounts of protein extracts were used. (A) GST-Mnk1 was recovered by glutathione-Sepharose chromatography. $(B)$ Specific immunoprecipitation of eIF4E. Proteins were resolved by SDS-PAGE and immunoblotted for eIF4G, eIF4E, GST, or 4E-BP1. (C) Cells were labeled in vivo with ${ }^{32} \mathrm{PO}_{4}$, eIF4E was recovered by immunoprecipitation and equal fractions were resolved by SDS-PAGE and autoradiography. Results are typical of at least three independent experiments and were quantitated by digital densitometry. reduced by $\sim 15$-fold during heat shock (Fig. 2B, lanes 2,4), and as expected, eIF4E binding to 4E-BP1 increased (Fig. $2 \mathrm{~B}$, lanes 2,4$)$. The drug rapamycin activates $4 \mathrm{E}-\mathrm{BP}$ binding to eIF4E at normal temperature (Lin et al. 1994; Haghighat et al. 1995; Feigenblum and Schneider 1996). Studies were therefore performed at non-heat shock temperature to determine whether 4E-BP binding to eIF4E is sufficient to account for the dissociation of eIF4E observed during heat shock. When cells were treated with rapamycin for the same length of time as heat shock, but at non-heat shock temperature $\left(37^{\circ} \mathrm{C}\right), 4 \mathrm{E}-\mathrm{BP} 1$ complexed with eIF4E, reducing eIF4E interaction with eIF4G, but by only twofold (Fig. 2B, lanes 4, 5). Rapamycin also reduced the in vivo phosphorylation of eIF4E by twofold, consistent with the level of 4E-BP1 binding (Fig. 2C). A twofold decrease in eIF4E association with Mnk1 was observed in cells treated with rapamycin at $37^{\circ} \mathrm{C}$, again consistent with only a modest ability of 4E-BP to displace eIF4E (Fig. 2A,B, lanes 4, 5). These results demonstrate that heat shock disrupts the formation of eIF4F complexes much more severely, and impairs eIF4E phosphorylation much more strongly, than observed for 4E$\mathrm{BP}$ alone. We therefore investigated mechanisms other than activation of 4E-BP that might be responsible for inhibition of translation during heat shock.

eIF4G is insolubilized and the cap-initiation complex dissociated in response to heat shock

Because eIF4G is degraded in mammalian cells during apoptosis (Marissen and Lloyd 1998), we first investigated whether degradation of eIF4G is responsible for inhibition of cap-dependent protein synthesis during heat shock. 293T cells were heat-shocked for the times shown, and endogenous eIF4G, eIF4E, eIF4A, eIF4B, eIF3, or PABP were detected by immunoblot analysis (Fig. 3A). Using standard cell lysis conditions to extract soluble proteins (nonionic detergent), soluble eIF4G progressively decreased during heat shock, whereas the levels of soluble eIF4E, eIF4A, eIF4B, eIF3 (four subunits are shown), and PABP were unchanged (Fig. 3A). To determine whether eIF4G is degraded or insolubilized, wholecell lysates were prepared using harsh extraction procedures (ionic-detergent and denaturation) to solubilize proteins. Equal levels of eIF4G were now evident (Fig. $3 \mathrm{~A}$, right), indicating that heat shock results in insolubilization of eIF4G, rather than degradation. Moreover, there was no evidence for smaller eIF4G protein fragments (data not shown), in contrast to results from apoptotic cells. The phosphorylation of eIF4E was blocked during heat shock (Fig. 3B) in parallel with the insolubilization of eIF4G, and the inhibition of non-heat shock protein synthesis, measured by incorporation of $\left[{ }^{35} \mathrm{~S}\right] \mathrm{me}$ thionine into polypeptides (Fig. 3C). Thus, between 1 and $2 \mathrm{hr}$ of heat shock treatment, the eIF4G component of the eIF4F/cap-initiation complex is specifically insolubilized, eIF4E is largely dephosphorylated, and cap(eIF4F)-dependent protein synthesis is strongly inhibited.

The time course for dissociated of the cap-initiation 


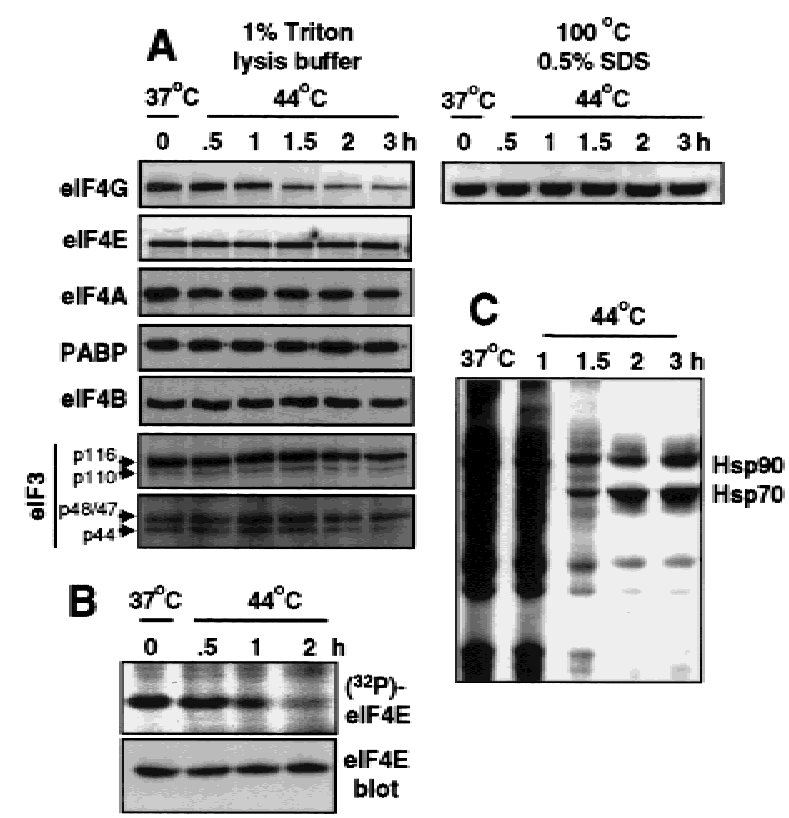

Figure 3. Heat shock induces insolubilization of eIF4G. 293T cells were maintained at $37^{\circ} \mathrm{C}$ or heat shocked at $44^{\circ} \mathrm{C}$ for the times shown. (A) Cell extracts were prepared using nonionic detergent (Triton X-100) or ionic detergent (SDS at $100^{\circ} \mathrm{C}$ ) to solubilize proteins, equal amounts were resolved by SDS-PAGE and immunoblotted for eIF4G, eIF4E, eIF4A, eIF4B, eIF3, or PABP. Four subunits of eIF3 are shown. (B) Cells were labeled in vivo with ${ }^{32} \mathrm{PO}_{4}$ during the time course of heat shock, eIF4E was recovered by immunoprecipitation and analyzed as described in the legend to Figure 2. $(C)$ Cells were labeled in vivo with 50 $\mu \mathrm{Ci} / \mathrm{ml}$ of $\left[{ }^{35} \mathrm{~S}\right]$ methionine for $30 \mathrm{~min}$ during heat shock as shown, equal amounts of protein extracts were resolved by SDSPAGE and fluorographed. Results are typical of at least three independent experiments and were quantitated by digital densitometry.

complex/eIF4F during heat shock was examined. 293T cells were transiently transfected with GST- or GSTMnk1 expression vectors and heat-shocked for the times shown, and protein extracts were solubilized with nonionic detergent buffer (Fig. 4). GST proteins were purified by glutathione-Sepharose chromatography, or eIF4E was immunoprecipitated and associated proteins detected by immunoblot analysis. Insolubilization of eIF4G during heat shock coincided with dissociation of eIF4E and Mnk1, stabilizing at a 10-12-fold reduction in soluble eIF4G by 2 hr of heat shock (Fig. 4A). Immunoprecipitation of eIF4E demonstrated a 10-15-fold reduction in association with eIF4G by $2 \mathrm{hr}$ of heat shock (Fig. 4B). Consistent with the results of Figure 3, dissociation of eIF3, eIF4A, and PABP from eIF4G followed identical kinetics during heat shock (data not shown). Thus, heat shock mediates the selective insolubilization of eIF4G and dissociation of the eIF4F/cap-initiation complex.

Dissociation of the cap-initiation complex during heat shock involves insolubilization of eIF4G with Hsp27

Studies determined whether inhibition of cap-dependent mRNA translation and loss of cap-initiation complexes

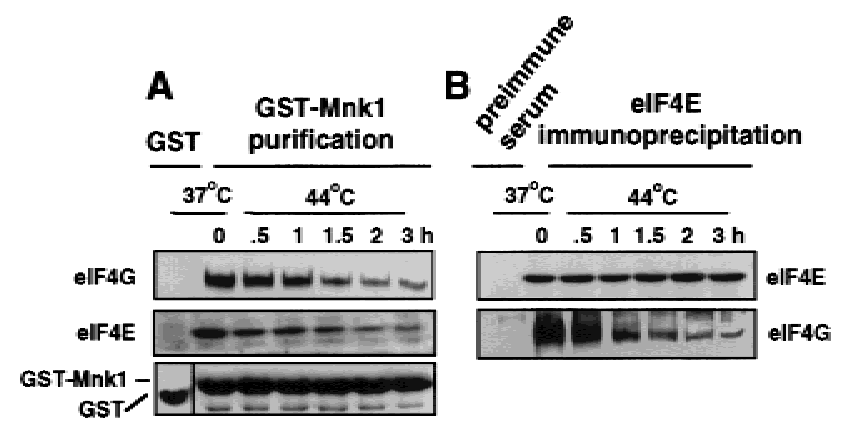

Figure 4. Loss of eIF4F complexes parallel eIF4G insolubilization. $293 \mathrm{~T}$ cells were transiently transfected with GST- or GST-Mnk1 expression vectors, maintained at $37^{\circ} \mathrm{C}$, or heatshocked for the times shown. Cells were extracted with nonionic detergent (Triton X-100) to purify soluble proteins. Equal amounts of extracts were used to recover GST-Mnk1 by glutathione-Sepharose chromatography $(A)$, or immunoprecipitate eIF4E with specific antisera $(B)$. Proteins were immunoblotted as shown. Results are typical of at least three independent experiments and were quantitated by digital densitometry.

involves de novo synthesis of Hsps. Inhibition of Hsp synthesis by cycloheximide treatment fully blocked insolubilization of eIF4G (Fig. 5A, left). Addition of cycloheximide $1.5 \mathrm{hr}$ after induction of heat shock, following the strong synthesis of Hsps (Fig. 3C), did not block the insolubilization of eIF4G (the majority of translation is that of Hsps after this time) (Fig. 5A, right). Identical results were obtained in HeLa cells (data not shown),

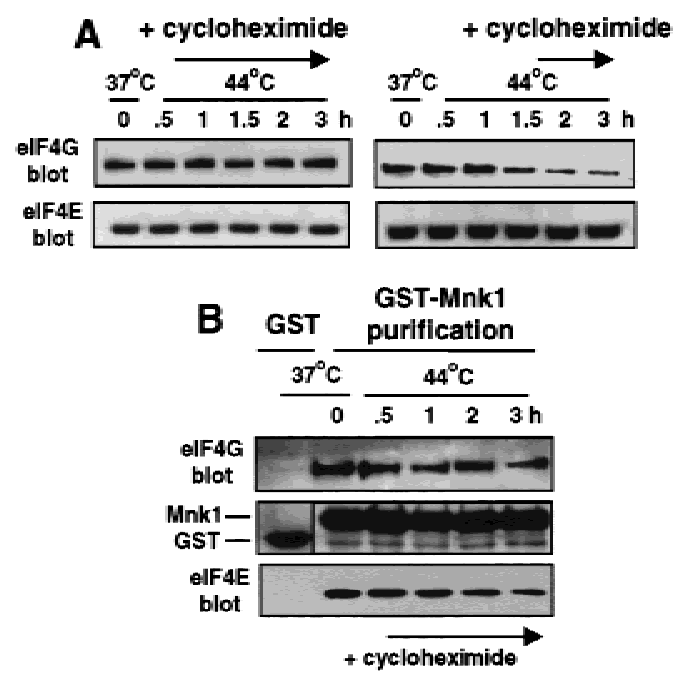

Figure 5. Proteins synthesized during heat shock mediate insolubilization of eIF4G. (A) $293 \mathrm{~T}$ cells were treated with cycloheximide at $50 \mu \mathrm{g} / \mathrm{ml}$ to prevent protein synthesis, then lysed in nonionic (Triton X-100) buffer to solubilize proteins at the indicated times. (B) $293 \mathrm{~T}$ cells transfected with GST-Mnk1 were treated with $50 \mu \mathrm{g} / \mathrm{ml}$ cycloheximide as shown, lysed in Triton X-100 buffer, and GST-Mnk1 was purified by glutathione-Sepharose chromatography. Proteins were resolved by SDSPAGE and immunoblotted with specific antisera as shown. 
Cuesta et al.

demonstrating that heat shock insolubilization of eIF4G is not cell-type specific and involves the nascent synthesis of one or more Hsps. Studies next determined whether the dissociation of cap-initiation complexes also requires synthesis of Hsps. $293 \mathrm{~T}$ cells transfected with GST-Mnk1 were treated with cycloheximide during heat shock, GST-Mnk1 was recovered, and associated proteins were detected by immunoblot analysis. In the absence of Hsp synthesis, the abundance of eIF4GeIF4E-Mnk1 complexes was reduced by twofold at 2-3 hr of heat shock, compared with 10-fold with ongoing Hsp synthesis (cf. Figs. 4A and 5B). Because the vast majority of protein synthesis during heat shock corresponds to Hsps, we determined whether particular Hsps specifically promote loss of cap-initiation complexes and insolubilization of eIF4G.

Heat shock induces formation of heat shock granules, which consist largely of Hsp27 and smaller amounts of Hsp70, in combination with a small number of non-Hsps identified to date. We therefore asked whether eIF4G is specifically insolubilized during heat shock by binding Hsp27, and possibly Hsp70. Studies first determined whether eIF4G is coinsolubilized during heat shock with Hsp27 and possibly Hsp70. 293T cells were heat-shocked for $2 \mathrm{hr}$, and cell lysates were prepared in ionic detergent to preserve strong protein interactions (RIPA buffer). Whole-cell lysates showed a four- to sixfold increased abundance of Hsp70 and Hsp27 with heat shock (Fig. 6A, compare lysate samples). During heat shock, Hsp27 and eIF4G were predominantly $(\sim 90 \%)$ coisolated in the insoluble protein fraction, whereas insoluble Hsp70 levels increased by only approximately twofold (Fig. 6A, compare insoluble protein lanes and total protein). Studies were therefore carried out to examine the proteins associated with eIF4G during heat shock. HA-eIF4G was expressed in transiently transfected cells at $37^{\circ} \mathrm{C}$ or during heat shock. Whole-cell lysates were then prepared using an ionic detergent (RIPA buffer, see Materials and Methods), but without abolishing protein-protein interactions. The total abundance of eIF4G, Hsp105, Hsc70, and Hsp40 proteins changed little during heat shock (Fig. 6B, left). The levels of Hsp90, Hsp70, Hsp60, and Hsp27 proteins increased variously from three- to sixfold with heat shock. Examination of HA-eIF4G during heat shock (Fig. 6B, right) showed no specific interaction with Hsp105, Hsp90, Hsp40, or Hsp60. Hsc70 coimmunoprecipitated with eIF4G at a low but constitutive level, as observed previously (Laroia et al. 1999). Hsp27 interaction with eIF4G was almost undetectable in non-heat-shocked cells, but increased strongly by 30 min of heat shock, and maximally by $1.5-2 \mathrm{hr}$. Hsp70 interaction with eIF4G increased about tenfold by $1-2 \mathrm{hr}$ of heat shock. These results demonstrate a strong and specific coassociation between eIF4G and Hsp27, with kinetics that parallel the dissociation of cap-initiation complexes, dephosphorylation of eIF4E, insolubilization of eIF4G and inhibition of non-Hsp synthesis.

eIF4G was found to colocalize in heat shock granules with Hsp27 during heat shock (Fig. 6C), consistent with the biochemical interaction results shown above. HeLa

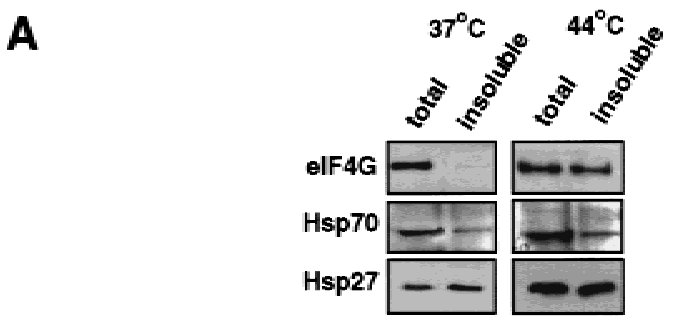

B
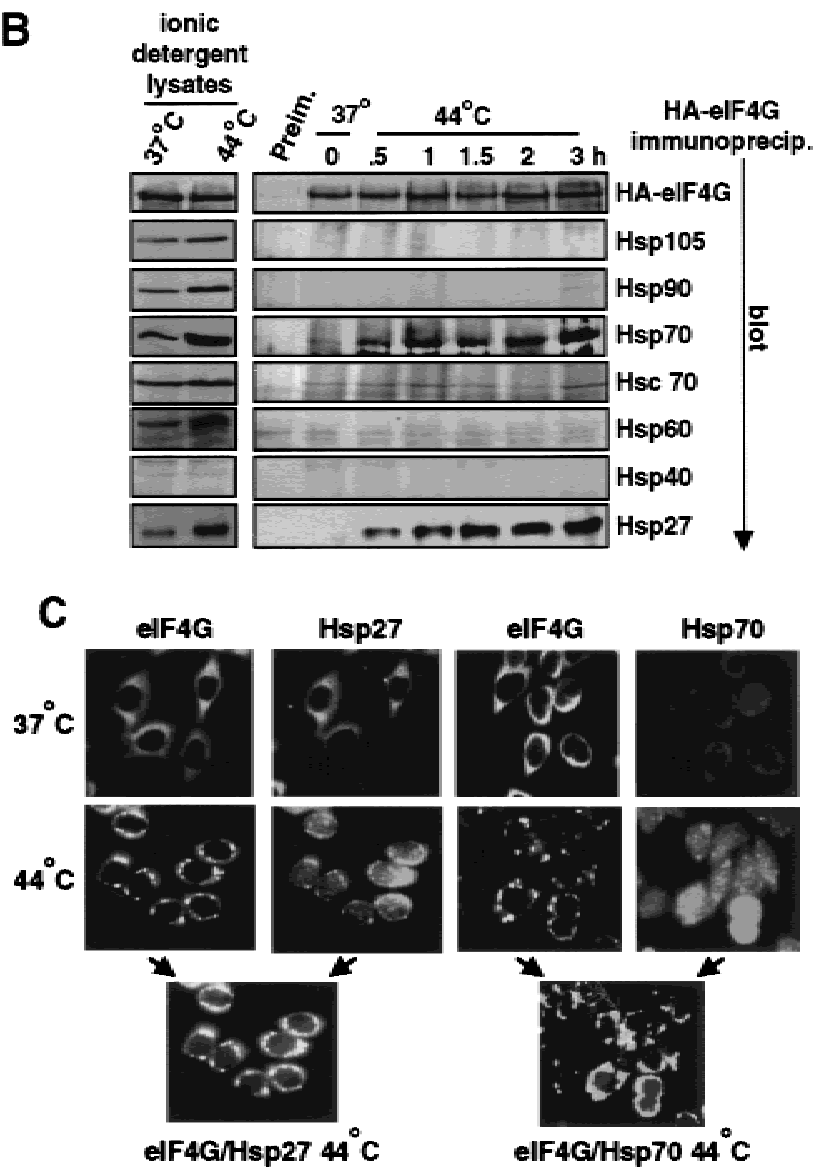

Figure 6. Chaperones associated with eIF4G. (A) $293 \mathrm{~T}$ cells were heat shocked at $44^{\circ} \mathrm{C}$ for $2 \mathrm{hr}$. Cells were lysed in RIPA detergent buffer. Whole-cell lysates containing total cell protein (total) were normalized for equal protein levels, insoluble protein pellets were recovered by glycerol gradient centrifugation, pellets were resolubilized in SDS with heating to $100^{\circ} \mathrm{C}$ and proteins were resolved by SDS-PAGE and immunoblotted as indicated (insoluble). (B) $293 \mathrm{~T}$ cells were transfected with an HA-epitope-tagged eIF4G expression vector and maintained at $37^{\circ} \mathrm{C}$ or heat-shocked at $44^{\circ} \mathrm{C}$. (Left) Cells were lysed as above; equal amounts were resolved by SDS-PAGE and immunoblotted, as shown. (Right) eIF4G was immunoprecipitated with antisera to the HA-epitope, or preimmune serum (Preim.), and precipitates were resolved by SDS-PAGE and immunoblotted with antisera as shown. Results were quantified by digital densitometry. (C) HeLa cells were grown on cover slips, heatshocked for $2 \mathrm{hr}$ at $44^{\circ} \mathrm{C}$ or maintained at $37^{\circ} \mathrm{C}$, fixed-permeabilized, and reacted with primary antibodies to eIF4G, Hsp27, or Hsp70, followed by staining with the following secondary antibodies: eIF4G, green fluorescence, Hsp27 or Hsp70, red fluorescence. Cells were visualized and photographed using a Zeiss Axiophot microscope. Coimaging analysis was performed by double-exposure using fluorescein and rhodamine-specific filters. 
cells were grown on cover slips, fixed-permeabilized, and stained with anti-eIF4G and anti-Hsp27 or antiHsp70 antibodies. Prior to heat shock, Hsp27 and Hsp70 demonstrated a weak, diffuse cytoplasmic distribution, indicated by weak immunofluorescence. eIF4G was distributed entirely in the cytoplasm, as expected. Heat shock induced an increase in Hsp27 protein fluorescence (abundance) and redistribution to perinuclear heat shock granules, which strongly colocalized with eIF4G, as shown in the merged images. Heat shock granules could not be solubilized by treatment of cells with nonionic detergent (data not shown), consistent with the results shown in Figures 3-5, and previous reports (e.g., Jakob et al. 1993). Heat shock increased the expression of Hsp70, some of which redistributed to perinuclear granules that contain eIF4G and Hsp27. The additional diffuse nuclear and cytoplasmic staining of Hsp70 is consistent with the large number of Hsp70-binding partners. These data independently demonstrate that eIF4G is specifically and strongly insolubilized with Hsp27 in response to heat shock.

Studies were therefore performed to test the role of Hsp27 in mediating inactivation of cap-dependent mRNA translation during heat shock. The highly related murine functional homolog of Hsp27, known as Hsp25, was overexpressed in transiently transfected $293 \mathrm{~T}$ cells. If Hsp27/25 functions to promote insolubilization of eIF4G and dissociation of eIF4F complexes, then with overexpression either the kinetics for eIF4G insolubilization, the extent of insolubilization, or both, should be enhanced during heat shock. Cells were cotransfected with a GST-Mnk1 expression vector and subjected to heat shock, Mnk1 was recovered by lysis with nonionic detergent buffer, and association of eIF4G and eIF4E was determined by immunoblot analysis (Fig. 7A). Control studies showed strong expression of Hsp25 in transfected cells (data not shown). In Hsp25-transfected cells, insolubilization of eIF4G and loss of eIF4E and Mnk1 was almost complete compared with control cells. This is most evident when comparing the loss of eIF4G and eIF4E from control cells $(90 \%$ reduction by $3 \mathrm{hr}$ ) to Hsp25transfected cells (almost undetectable by $3 \mathrm{hr}$ ). Maximum dissociation of eIF4F was also achieved slightly more rapidly in Hsp25 transfected cells (between 1-1.5 hr) compared with control cells (between 2-3 hr). In the absence of heat shock, overexpression of Hsp25 did not strongly increase eIF4G insolubilization /data not shown). This is consistent with the established role of heat shock activation of Hsp25/27 by mobilization from aggregates to a soluble form. Studies were also conducted to determine whether Hsp70 might block eIF4G insolubilization, consistent with its suspected role in protecting the translational machinery. Because continuous overexpression of Hsp70 is toxic, the constitutively acting form of Hsp70, Hsc70, was used. With overexpression of Hsc70 in transfected cells, eIF4G was no longer insolubilized and there was only a slight loss of eIF4E and Mnk1 binding to eIF4G during heat shock (Fig. 7A). Given the almost complete dissociation of eIF4E and Mnk1 from eIF4G in Hsp25-expressing cells, eIF4F-de- pendent (non-heat shock) protein synthesis and eIF4E phosphorylation would certainly be abolished.

\section{Sequestration of eIF4G and inhibition of translation are a direct effect of $\mathrm{Hsp} 27$ binding}

The in vivo studies described above can not exclude the possibility that inhibition of protein synthesis and insolubilization of eIF4G may be an indirect effect of heat shock, involving Hsp25/27 but is not mediated by them. Studies were therefore performed in vitro to determine whether Hsp27 can directly and specifically bind eIF4G, prevent protein synthesis, either remove eIF4G from eIF4F complexes, or prevent formation of eIF4F and insolubilize eIF4G. Studies were first carried out to determine whether Hsp27 directly and specifically binds a region of eIF4G in vitro. Regions of eIF4G corresponding to the amino-terminal (N4G), middle (M4G), and carboxy-terminal (C4G) third of the protein, as well as eIF4E, GST-Mnk1, and GST were expressed and purified from bacteria. It was not possible to purify sufficient amounts of full-length $220-\mathrm{kD}$ eIF4G because of degradation. Equal amounts $(0.5 \mu \mathrm{g})$ of each purified protein were resolved by SDS-PAGE, transferred to membrane, and subjected to far-Western analysis using purified, recombinant Hsp27 protein (Fig. 7B). Only the M4G region of eIF4G bound Hsp27. An M4G doublet results from partial cleavage at two sites by thrombin during purification. Control studies showed strong binding of the N4G region to eIF4E as expected (Fig. 7B, right), and binding of Mnk1 to the C4G region (data not shown), indicating that resolved polypeptides retained known protein-binding abilities.

The effect of Hsp27 on mRNA translation was investigated using in vitro translation extracts. Equal amounts of a luciferase reporter mRNA were translated in rabbit reticulocyte lysates (RRLs), with or without addition of purified, recombinant Hsp27 or Hsp70 (Fig. $7 \mathrm{C}$, top and middle). Recombinant Hsp27 is not phosphorylated and is equivalent to the heat shock-induced form of the protein. Translation was performed at $30^{\circ} \mathrm{C}$, or at a higher but still sub-heat shock temperature $\left(37^{\circ} \mathrm{C}\right)$. Addition of Hsp27 suppressed luciferase mRNA translation about two to threefold at $30^{\circ} \mathrm{C}$, whereas Hsp70 did not, compared with the unsupplemented control (Fig. 7C, top). However, at $37^{\circ} \mathrm{C}, \mathrm{Hsp} 27$ almost fully suppressed mRNA translation (Fig. 7C, middle). Because the translation lysates are more rapidly depleted at the higher temperature, shorter times were assayed. Immunoblot analysis demonstrated equal levels of translation factors in total lysates (Fig. 7C, bottom). As expected, Northern RNA analysis showed that the reporter mRNAs remained intact in all samples (data not shown). Thus, enhanced abundance of Hsp27, coupled with slightly elevated temperature, is sufficient to largely block protein synthesis.

It was then investigated whether purified (nonphosphorylated) Hsp27, when added to an in vitro translation system at sub-heat shock temperature, selectively binds eIF4G into insoluble complexes. Increasing amounts of 
Figure 7. Effect of Hsp25/27 and Hsc/Hsp70 on eIF4F complex and translation activity. $(A)$ 293 T cells were transfected with vectors expressing GST-Mnk1 and either murine Hsp25 or human Hsc70. Cells were maintained at $37^{\circ} \mathrm{C}$ or heat-shocked at $44^{\circ} \mathrm{C}$ for the times shown, soluble proteins were prepared, and GST-Mnk1 was recovered. Proteins were resolved by SDS-PAGE and immunoblotted as shown. (B) Equal amounts $(0.5 \mu \mathrm{g})$ of purified recombinant proteins as indicated were resolved by SDS-PAGE, transferred to membrane, and analyzed by far Western analysis by reacting with purified Hsp27 (left) or eIF4E (right), followed by antisera specific for Hsp27 or eIF4E, respectively, and ECL. Arrows indicate the electrophoretic positions of indicated proteins determined by staining the membrane with Coomassie blue (not shown). (C) Equal amounts of a luciferase reporter mRNA were translated in RRLs containing $\left[{ }^{35} \mathrm{~S}\right] \mathrm{me}$ thionine, with and without addition of purified Hsp27 or Hsp70, at $30^{\circ} \mathrm{C}$ or $37^{\circ} \mathrm{C}$. Translation products were resolved by SDS-PAGE. Western immunoblot of equal amounts of RRL with specific antisera as shown. $(D) \mathrm{Pu}-$ rified recombinant Hsp27 was added to $50 \mu \mathrm{l}$ of RRL at $37^{\circ} \mathrm{C}$ for $30 \mathrm{~min}$, then insoluble and soluble fractions were prepared. (Left) All of the insoluble and one-third of the soluble fractions were resolved by SDS-PAGE and immunoblotted with antisera as shown. (Right) After removal of the insoluble protein fraction from control and Hsp27 containing samples, immunoprecipitation of Hsp27 or eIF4G was carried out using the soluble protein fraction, after normalization for eIF4G, followed by immunoblot analysis with antisera as shown. One-third volume of lysate was resolved as a control. Results are typical of at least three independent experiments and were quantitated by digital densitometry.
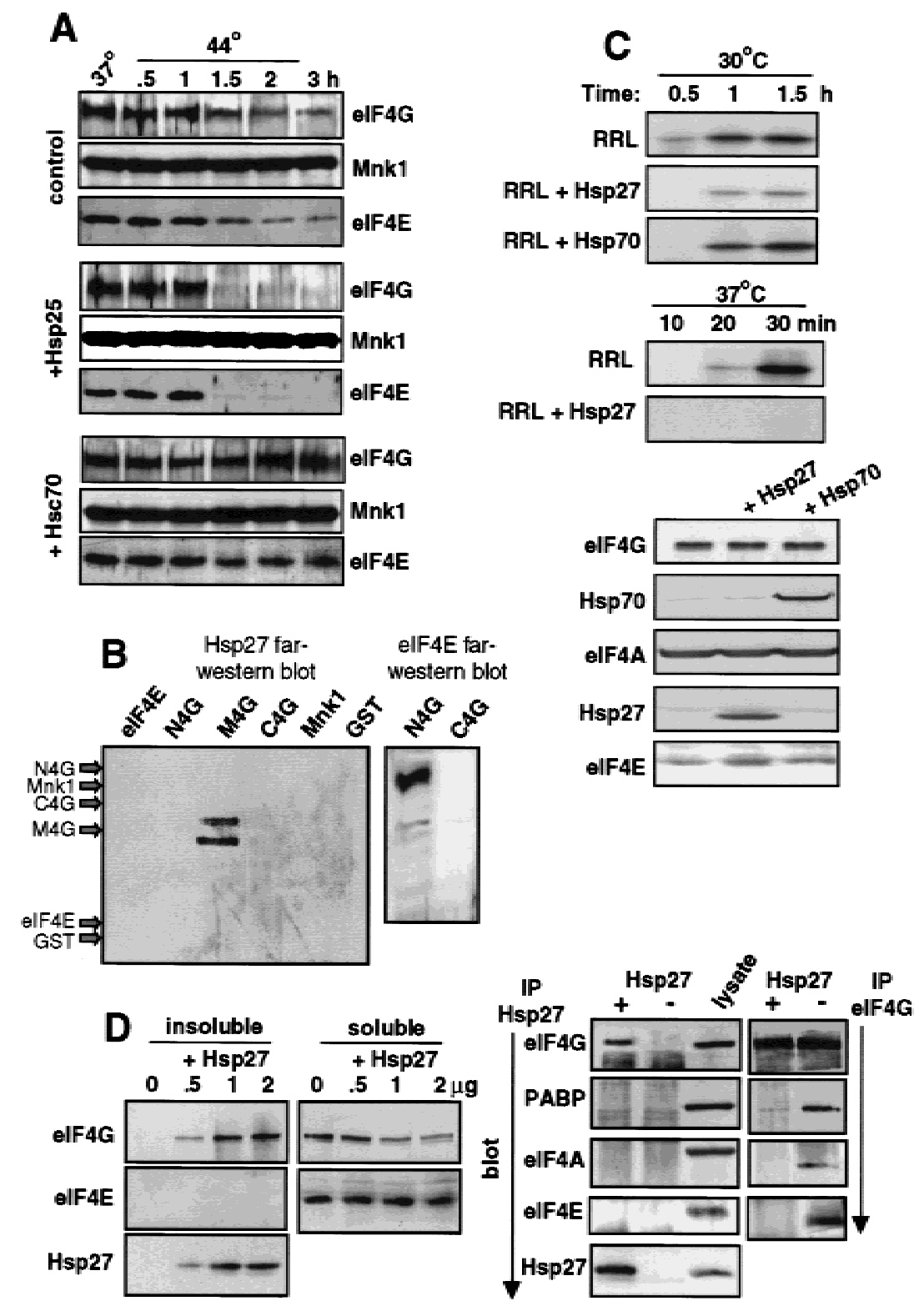

purified Hsp27 were added to rabbit reticulocyte in vitro translation extracts at $37^{\circ} \mathrm{C}$ for $30 \mathrm{~min}$, as in translation studies (Fig. 7C). Soluble and insoluble fractions were recovered and examined for eIF4G, eIF4E, and Hsp27 proteins by immunoblot analysis (Fig. 7D, left). In the absence of Hsp27 addition, eIF4G and eIF4E proteins remained soluble. With addition of increasing amounts of Hsp27 to the same final concentration that extinguished in vitro protein synthesis $(2 \mu \mathrm{g})$, much of eIF4G but not eIF4E became insoluble and partitioned with Hsp27. There was also no evidence for increased insolubilization of PABP and eIF4A with addition of Hsp27 (data not shown), consistent with in vivo results. Importantly, immunoprecipitation of Hsp27 from the soluble fraction, after removal of insoluble complexes, recovered residual eIF4G, but not PABP, eIF4E, or eIF4A (Fig. 7D, right). Immunoprecipitation of eIF4G from these same samples, previously normalized for eIF4G levels, did not show binding of eIF4A, PABP, and eIF4E to eIF4G with addition of Hsp27. There was a slight retention of PABP on eIF4G in the Hsp27 samples, which was not observed in vivo. In contrast, in the absence of added Hsp27, eIF4G immunoprecipitation recovered eIF4E, eIF4A, and PABP, as expected (Fig. 7D, right). Thus, at least some of eIF4G that is bound to Hsp27 is devoid of eIF4F components prior to insolubilization. These data confirm the selective binding of Hsp27 to eIF4G, and they indicate that Hsp27 most likely functions to prevent eIF4F complex formation by eIF4G.

\section{Discussion}

This study has characterized how heat shock triggers inhibition of protein synthesis. We have shown that the 
chaperone Hsp27 participates in inhibition of eIF4F(cap)dependent translation initiation by binding eIF4G, which is associated with a significant reduction in formation of eIF4F complexes and insolubilization of eIF4G. The results largely account for the inhibition of eIF4E phosphorylation, the disassembly of initiation factor eIF4F, and impaired eIF4F-dependent mRNA translation that is a hallmark of heat shock (Duncan et al. 1987; Duncan and Hershey 1989; Lamphear and Panniers 1990; Zapata et al. 1991; Feigenblum and Schneider 1996). The continued translation of heat shock mRNAs occurs because they require minimal amounts of eIF4F, either by virtue of initiation through internal ribosome entry, or by ribosome shunting mechanisms (Yueh and Schneider 2000; for review, see Schneider 2000).

It is significant that heat shock, in the absence of Hsp synthesis, was not sufficient to strongly insolubilize eIF4G (Fig. 5). These results implicated overexpression of certain Hsps in dissociation of the cap-initiation complex (eIF4F). Hsp27 was the only Hsp to significantly coisolate with eIF4G, and with kinetics coincident with inhibition of translation and insolubilization of eIF4G (Fig. 6B). Moreover, overexpression of Hsp25, the murine homolog of human Hsp27, enhanced the magnitude of eIF4G insolubilization during heat shock, whereas overexpression of Hsp70 prevented it (Fig. 7A). These data indicate that some members of the small Hsp family (Hsp25-27) play an important role in regulating the level of eIF4F availability for protein synthesis.

Studies have shown previously that in normal cells Hsp25/27 are found in large insoluble complexes. Heat shock induces rapid phosphorylation of these proteins, which is linked to solubilization, followed by dephosphorylation and insolubilization into perinuclear heat shock granules (Landry et al. 1991; Lambert et al. 1999; Rogalla et al. 1999/. New synthesis of Hsp25/27 also occurs. The chaperone function of Hsp25-27, the ability to bind to unfolding proteins and to protect unfolding proteins against irreversible denaturation, involves the temporally late insolubilization of Hsp25-27 during heat shock (Lambert et al. 1999; Rogalla et al. 1999). The insolubilization of eIF4G (Fig. 3) and the loss of eIF4F mediated by Hsp27 (Fig. 6B) is consistent with this kinetic profile. Insolubilization of Hsp27 during heat shock is associated with a dramatic increase in cell survival (Jakob et al. 1993; Carper et al. 1997; Ehrnsperger et al. 1997), linked in part to the ability of Hsp27 to protect the translation machinery during recovery from heat shock (Liu et al. 1992; Li et al. 1995; Carper et al. 1997). Hsp27 traps unfolding protein intermediates, preventing irreversible denaturation and aggregation, but it does not actually chaperone protein refolding during recovery from heat shock. In our studies, the inhibition of nonHsp synthesis during heat shock was in accord with the insolubilization of eIF4G by Hsp27. There was no evidence for insolubilization of other eIF4G-associated factors, including eIF4E, eIF4A, eIF3, Mnk1, and PABP (Figs. $3,4,7)$. There was also little evidence for insolubilization of eIF4G with any other Hsp chaperones, other than Hsp27 (Fig. 6B). This indicates a specificity to the inter- action, as opposed to the mere binding of Hsp27 to denatured eIF4G. This is also supported by the specific in vitro binding of $\mathrm{Hsp} 27$ to the middle region of eIF4G (Fig. 7B). Finally, as some soluble eIF4G was complexed with Hsp27 and was devoid of eIF4E, eIF4A, and PABP (Fig. 7D), typical components of the eIF4F complex, this raises two possible mechanism of action whereby translation is inhibited by Hsp27. Hsp27 may preferentially interact with eIF4G that is within the eIF4F complex, thereby acting to remove associated proteins. However, we believe that it is most likely that Hsp27 preferentially binds to eIF4G that is no longer within the eIF4F complex, thereby acting to shift the equilibrium to eIF4G removal. It is thought that factors frequently cycle on and off eIF4G, making this second possibility more attractive. It is also not known whether Hsp27 binding to the central region of eIF4G leads directly to its insolubilization, or represents a primary interaction site followed by other sites of interaction with Hsp27, leading to eIF4G insolubilization.

An observation of this work that will require additional study is the possibility that Mnk1 might be freed of eIF4G to then participate in a heat shock signal transduction response. Mnk1 retains kinase activity during heat shock (Fig. 1), despite displacement from eIF4G. Mnk1 is a member of the MAP kinase-activated protein kinase (MAPKAPK) family (Fukunaga and Hunter 1997; Waskiewicz et al. 1997), and like other members of this family, it is activated by the cell stress-activated p38 kinases. It is significant that Mnk1 shares about 30\% identity to MAPKAPKs and to a newly identified p38regulated/activated protein kinase (PRAK), which can phosphorylate Hsp27 in response to cell stress (New et al. 1998). It is possible that Mnk1 might participate in phosphorylation of insolubilized Hsp27 protein, thereby promoting the disaggregation of eIF4G from heat shock granules and the reactivation of eIF4F(cap)-dependent protein synthesis.

\section{Materials and methods}

Plasmids

Plasmids pEBG-Mnk1, PGEX-Mnk1, pEBG-Mnk1 (T2A2) (Waskiewicz et al. 1997) (kindly provided by J.A. Cooper), pcDNA-HA-eIF4GI (Imataka et al. 1997) (a gift of N. Sonenberg), pcDNA-Hsc70 (gift from C. Daly), and pCIneo-Hsp25 (gift from J. Landry) were described previously. Plasmids expressing GST-fusion amino-terminal (157-626), middle (627-1045), and carboxy-terminal (1045-1560) segments of eIF4GI were constructed as follows. An EcoRI-XhoI fragment was prepared by PCR amplification of the corresponding eIF4GI sequence using specific primers and cloned into an EcoRI/XhoI-digested pGEX4T-I vector (Amersham Pharmacia Biotech). The primers used to amplify each segment were 5'-CCCCGAATTCATGTCTGGGGCCCGC-3' and 5'-CAACCTCGAGTCAGAAGTCTGGGCC-3' for the amino-terminal; 5'-CAACGAATTCACTCCATCCTTTGCC- $3^{\prime}$ and $5^{\prime}$-AAAACTCGAGTCAGAGCTGGTTGTTAG-3' for the middle fragment and 5'-CAACGAATTCCTCTTTGCACCTGGAG-3' and 5'-CAACCTCGAGTCAGACTCCTCCTCTG-3' for the carboxy-terminal segment of eIF4GI. 


\section{Cell culture and transient transfection}

293 cells are a human embryonic kidney cell line transformed with the E1 region of Ad5. 293T cells express the SV40 TAg. 293, 293T, and HeLa cells were grown in Dulbecco's modified Eagle's medium (DMEM; Gibco) supplemented with 10\% calf serum (Hyclone). For transient transfection, $1 \times 10^{6} 293$ or $293 \mathrm{~T}$ cells were passaged onto $10-\mathrm{cm}$ plates $24 \mathrm{hr}$ prior to calcium phosphate precipitation with $5 \mu \mathrm{g}$ of each plasmid. Cells were harvested and lysed 48-72 hr later. Heat shock of cells was carried out at $44^{\circ} \mathrm{C}$ for $2 \mathrm{hr}$ unless otherwise stated. To stimulate cells with EGF (Sigma), they were first serum starved for 24 $\mathrm{hr}$ in serum-free medium then treated with EGF $(30 \mathrm{ng} / \mathrm{ml})$ for 15 min. Rapamycin (Calbiochem) was added to the cells at a final concentration of $20 \mathrm{ng} / \mathrm{ml}$ and incubation was continued either at $37^{\circ} \mathrm{C}$ or $44^{\circ} \mathrm{C}$. Cycloheximide (Calbiochem) was used at $50 \mu \mathrm{g} / \mathrm{ml}$.

\section{GST protein purification}

To obtain GST fusion proteins from mammalian cells, 293 or $293 \mathrm{~T}$ cells were transiently transfected for 48-72 hr with pEBGMnk1, pEBG-Mnk1 (T2A2), or pEBG, lysed in Triton lysis buffer (1\% Triton X-100, $50 \mathrm{~mm} \mathrm{NaF}, 10 \mathrm{~mm}$ HEPES at $\mathrm{pH}$ 7.4, $2 \mathrm{~mm}$ EDTA, $2 \mathrm{~mm}$ sodium orthovanadate, $0.1 \% \beta$-mercaptoethanol, $1 \mu \mathrm{g} / \mathrm{ml}$ aprotinin, $1 \mu \mathrm{g} / \mathrm{ml}$ leupeptin, $1 \mathrm{~mm}$ PMSF), and lysates clarified by centrifugation for $15 \mathrm{~min}$ at $14,000 \mathrm{~g}$ at $4^{\circ} \mathrm{C}$. GST proteins were purified with glutathione-Sepharose $4 \mathrm{~B}$ (Pharmacia) for $1 \mathrm{hr}$ at $4^{\circ} \mathrm{C}$, beads were collected by centrifugation and washed $3 \times$ with Triton lysis buffer (for copurification experiments) or once with lysis buffer containing $0.5 \mathrm{M} \mathrm{LiCl}$ and $3 \times$ with lysis buffer without $\mathrm{LiCl}$ (for in vitro kinase assays). GST fusion proteins were purified from Escherichia coli BL21 as described Smith and Johnson (1988). Removal of the GST affinity tail from GST-N4G, GST-M4G, and GST-C4G was carried out by thrombin cleavage.

\section{Immunoprecipitation and insoluble-soluble protein analysis}

293, 293T, or HeLa cells were lysed 48-72 hr post-transfection in Nonidet P-40 lysis buffer $(0.5 \%$ NP- $40,50 \mathrm{~mm}$ HEPES at $\mathrm{pH}$ 7.0, $250 \mathrm{~mm} \mathrm{NaCl}, 2 \mathrm{~mm}$ EDTA, $2 \mathrm{~mm}$ sodium orthovanadate, $25 \mathrm{~mm}$ glycerophosphate, $1 \mu \mathrm{g} / \mathrm{ml}$ aprotinin, $1 \mu \mathrm{g} / \mathrm{ml}$ leupeptin, $1 \mathrm{~mm}$ PMSF). Lysates were clarified by centrifugation for $15 \mathrm{~min}$ at $14,000 \mathrm{~g}$. The pellet was retained as the insoluble fraction, the supernatant as soluble protein. Pellets were resuspended in RIPA buffer as below. Harsh lysis conditions were carried out in RIPA buffer ( $1 \%$ NP- $40,0.5 \%$ sodium deoxycholate, $0.1 \%$ SDS, $150 \mathrm{~mm} \mathrm{NaCl}, 50 \mathrm{~mm}$ Tris- $\mathrm{HCl}$ at $\mathrm{pH} 8.0,2 \mathrm{~mm}$ EDTA, $2 \mathrm{~mm}$ sodium orthovanadate, $50 \mathrm{~mm} \mathrm{NaF}, 1 \mu \mathrm{g} / \mathrm{ml}$ aprotinin, $1 \mu \mathrm{g} / \mathrm{ml}$ leupeptin, $1 \mathrm{mM}$ PMSF). If used directly for Western blotting, cells were incubated at $100^{\circ} \mathrm{C}$ for $2 \mathrm{~min}$ in SDS lysis buffer (0.5\% SDS, $50 \mathrm{~mm}$ Tris- $\mathrm{HCl}$ at $\mathrm{pH} 8.0,1 \mathrm{~mm}$ DTT) followed by SDS-polyacrylamide gel electrophoresis. Lysates were incubated for $2 \mathrm{hr}$ at $4^{\circ} \mathrm{C}$ with $2 \mu \mathrm{g} / \mathrm{ml}$ RNase A and rabbit polyclonal serum against eIF4E (Feigenblum and Schneider 1996), or mouse anti-HA monoclonal antibody (12CA5, Roche Molecular Biochem.). Either protein A- or G-agarose was added and incubation continued for $1 \mathrm{hr}$ at $4^{\circ} \mathrm{C}$. Precipitates were washed $3 \times$ with lysis buffer, boiled in Laemmli sample buffer, and analyzed by SDS-PAGE.

\section{Immunoblotting}

Gels were electroblotted onto Immobilon-P membrane (Millipore), blocked 12-15 hr in blocking buffer (150 mM NaCl, $10 \mathrm{~mm}$
Tris- $\mathrm{HCl}$ at $\mathrm{pH} 8.0,5 \%$ nonfat dry milk (NFDM)] at $4^{\circ} \mathrm{C}$. Immune reagents were rabbit polyclonal antisera to eIF4G (gift of Dr. L. Carrasco, CSK/Universidad Autonoma, Madrid, Spain), polyclonal goat antisera to eIF3 (gift of W. Merrick, Case Western Reserve University), antisera to eIF4B (gift of N. Sonenberg, McGill University), affinity-purified rabbit polyclonal antibody to GST (no. Z-5, Santa Cruz Biotech.), rabbit polyclonal antieIF4E antiserum, rabbit anti-BP1 polyclonal antibody, goat polyclonal antibody to Hsp70 (no. K-20, Santa Cruz Biotech.), mouse monoclonal antibody to Hsp27 (Stressgen Biotech.), goat antiHsc70 polyclonal antibody (no. K-19, Santa Cruz Biotech.), mouse anti-Hsp90 monoclonal antibody (StressGen Biotech), goat polyclonal antibody to Hsp40 (no. N-19, Santa Cruz Biotech), guinea pig anti-Hsp60 polyclonal antibody (gift of $\mathrm{N}$. Cowan, New York University), rabbit anti-Hsp105 polyclonal antibody (no. N-187, Santa Cruz Biotech), horseradish peroxidase-conjugated donkey anti-rabbit or sheep anti-mouse secondary antibodies (Amersham), horseradish peroxidase-conjugated donkey anti-goat (no. SC-2033, Santa Cruz Biotech), mouse anti-HA monoclonal antibody (12CA5, Roche Molecular Biochem.), and enhanced chemiluminescence system (ECL; Amersham).

\section{Far Western analysis}

Purified N4G, M4G, C4G, eIF4E, GST-Mnk1, and GST were resolved by electrophoresis in a $10 \%$ SDS-polyacrylamide gels and transferred to Immobilon-P membrane (Millipore). Membrane was blocked for $16 \mathrm{hr}$ at $4^{\circ} \mathrm{C}$ in TBS containing $5 \%$ nonfat dry milk and then incubated for $2 \mathrm{hr}$ at RT in blocking buffer containing $1 \mu \mathrm{g} / \mathrm{ml}$ of either human Hsp27 (Stressgen Biotech.) or eIF4E. Following 3 washes with TBS, complexes were detected as described above for immunoblotting.

\section{Metabolic labeling of cells}

Cells were labeled with $50 \mu \mathrm{Ci}$ of $\left[{ }^{35} \mathrm{~S}\right]$ methionine per $\mathrm{ml}$ (Easytag Express Protein Labeling Mix, Dupont/NEN) in DMEM without methionine for $30 \mathrm{~min}$. Cells were lysed in $0.5 \% \mathrm{NP}-40$ lysis buffer at $4^{\circ} \mathrm{C}$ and sonicated $2 \times$ for $30 \mathrm{sec}$, and equal amounts of protein were analyzed by SDS-PAGE and fluorography. Specific activity was determined by trichloroacetic acid precipitation and liquid scintillation. For ${ }^{32} \mathrm{PO}_{4}$ labeling, cells were washed $2 \times$ with phosphate-free DMEM (Gibco) incubated at $37^{\circ} \mathrm{C}$ for $30 \mathrm{~min}$ in this medium supplemented with $1 \%$ dialyzed fetal bovine serum, then labeled for $2 \mathrm{hr}$ in $\left[{ }^{32} \mathrm{P}\right]$ orthophosphate $(0.1 \mathrm{mCi} / \mathrm{ml}$; DuPont/NEN). Cells were lysed in $0.5 \%$ NP-40 buffer and eIF4E was immunoprecipitated as described above.

\section{Kinase assays}

Wild-type Mnk1 and a catalytically inactive Mnk1 (T2A2) were assayed for kinase activity in vitro by addition of $1 \mu \mathrm{g}$ purified eIF4E to a purified GST-bead mixture. Kinase-substrate reactions were carried out at $30^{\circ} \mathrm{C}$ for $20 \mathrm{~min}$ in kinase buffer [20 mM HEPES at $\mathrm{pH} 7.4,10 \mathrm{~mm} \mathrm{MgCl}_{2}, 10 \mathrm{~mm} \beta$-glycerophosphate, $2 \mathrm{~mm}$ sodium orthovanadate, $1 \mathrm{~mm}$ DTT, $25 \mu \mathrm{M}$ ATP, $10 \mu \mathrm{Ci}$ $\left[\gamma^{-32} \mathrm{P}\right]$ ATP $\left.(3,000 \mathrm{Ci} / \mathrm{mmol})\right]$. Products were resolved by SDSPAGE and visualized by autoradiography.

\section{Immunofluorescence microscopy}

HeLa cells grown on coverslips were heat-shocked for the indicated times, $24 \mathrm{hr}$ after passage. Cells were fixed with acetone/ methanol $(7: 3)$ for $7 \mathrm{~min}$ at $-20^{\circ} \mathrm{C}$, blocked in $1 \times \mathrm{PBS}-1 \%$ NFDM for $30 \mathrm{~min}$ at $25^{\circ} \mathrm{C}$, then incubated with antibodies against eIF4G, Hsp70, or Hsp27 in PBS-1\% NFDM for $1 \mathrm{hr}$ at 
$37^{\circ} \mathrm{C}$ in a humidified chamber. Fixed cells were washed $4 \times$ with PBS-1\% NFDM, reacted with anti-rabbit IgG-fluorescein, $\mathrm{F}\left(\mathrm{ab}^{\prime}\right)_{2}$ fragment and anti-mouse Ig(polyvalent)-rhodamine, $\mathrm{F}\left(\mathrm{ab}^{\prime}\right)_{2}$ fragment for $1 \mathrm{hr}$ at $37^{\circ} \mathrm{C}$ in a humidified chamber, then washed $4 \times$ with PBS-1\% NFDM and mounted using Victashield mounting media (Vector Laboratories).

\section{In vitro translation studies}

Equal amounts of in vitro transcribed luciferase mRNA were translated in $40 \mu \mathrm{l}$ of RRL (Promega) supplemented with $20 \mu \mathrm{Ci}$ of $\left[{ }^{35} \mathrm{~S}\right]$ methionine, or in RRL containing $2 \mu \mathrm{g}$ of purified recombinant Hsp27 or Hsp70 (Stressgen) at $30^{\circ} \mathrm{C}$ for up to $2 \mathrm{hr}$ or at $37^{\circ} \mathrm{C}$ for up to $30 \mathrm{~min}$. Equal aliqouts were removed at different time points, resolved by SDS-PAGE, and visualized by autoradiography or immunoblotting. Equal aliqouts were partitioned into insoluble protein by centrifugation in a microfuge at $14,000 \mathrm{~g}$ for $5 \mathrm{~min}$ at $4^{\circ} \mathrm{C}$, and the supernatant was retained as the soluble fraction.

\section{Acknowledgments}

We thank N. Sonenberg for the HA-eIF4GI clone and antisera to eIF4B, J. Landry for the Hsp25 clone, J. Cooper for GST-Mnk1 clones, I. Novoa and L. Carrasco for antisera to eIF4G, G. Dreyfuss for PABP antibody, and N. Cowan for Hsp60 antibodies, and W. Merrick for eIF3 antisera. This work was supported by NIH grant CA 42357 (to R.J.S.) and by a fellowship from Fundacion Ramon Areces, Spain (to R.C.).

The publication costs of this article were defrayed in part by payment of page charges. This article must therefore be hereby marked "advertisement" in accordance with 18 USC section 1734 solely to indicate this fact.

\section{References}

Beretta, L., A.-C. Gingras, Y.V. Svitkin, M.N. Hall, and N. Sonenberg. 1996. Rapamycin blocks the phosphorylation of 4E-BP1 and inhibits cap-dependent initiation of translation. EMBO J. 15: 658-664.

Carper, S.W., T. Rocheleau, D. Cimino, and F.K. Storm. 1997. Hsp 27 stimulates recovery of RNA and protein synthesis following a heat shock. J. Cell. Biochem. 66: 153-164.

Craig, E.A., J.S. Weissman, and A.L. Horwich. 1994. Hsps and molecular chaperones: mediators of protein conformation and turnover in the cell. Cell 78: 365-372.

Duncan, R.F. 1996. Translational control during heat shock. In Translational control (ed. J.W.B. Hershey, M.B. Mathews, and N. Sonenberg), pp. 271-294. Cold Spring Harbor Laboratory Press, Cold Spring Harbor, NY.

Duncan, R.F. and J.W.B. Hershey. 1989. Protein synthesis and protein phosphorylation during heat stress, recovery, and adaptation. J. Cell. Biol. 109: 1467-1481.

Duncan, R., S.C. Milburn, and J.W.B. Hershey. 1987. Regulated phosphorylation and low abundance of Hela cell initiation factor eIF-4F suggest a role in translational control. J. Biol. Chem. 262: 380-388.

Ehrnsperger, M., S. Graber, M. Gaestel, and J. Buchner. 1997. Binding of nonnative protein to Hsp25 during heat shock creates a reservoir of folding intermediates for reactivation. EMBO J. 16: 221-229.

Feigenblum, D. and R.J. Schneider. 1993. Modification of eukaryotic initiation factor 4F during infection by influenza virus. J. Virol. 67: 3027-3035.

1996. Cap-binding protein (eukaryotic initiation factor
4E) and 4E-inactivating protein BP-1 independently regulate cap-dependent translation. Mol. Cell. Biol. 16: 5450-5457.

Feigenblum, D., R. Walker, and R.J. Schneider. 1998. Adenovirus induction of an interferon-regulatory factor during entry into the late phase of infection. J. Virol. 72: 9257-9266.

Fukunaga, R. and T. Hunter. 1997. MNK1, a new MAP kinaseactivated protein kinase, isolated by a novel expression screening method for identifying protein kinase substrates. EMBO J. 16: 1921-1933.

Glover, J.R. and S. Lindquist. 1998. Hsp104, Hsp70, and Hsp40: A novel chaperone system that rescues previously aggregated proteins. Cell 94: 73-82.

Haghighat, A., S. Mader, A. Pause, and N. Sonenberg. 1995. Repression of cap-dependent translation by $4 \mathrm{E}$-binding protein 1: Competition with p220 for binding to eukaryotic initiation factor-4E. EMBO J. 14: 5701-5709.

Huang, J. and R.J. Schneider. 1991. Adenovirus inhibition of cellular protein synthesis involves inactivation of cap binding protein. Cell 65: 271-280.

Imataka, H., H.S. Olsen, and N. Sonenberg. 1997. A new translational regulator with homology to eukaryotic translation initiation factor 4G. EMBO T. 16: 817-825.

Imataka, H., A. Gradi, and N. Sonenberg. 1998. A newly identified N-terminal amino acid sequence of human eIF4G binds poly(A)-binding protein and functions in poly(A)-dependent translation. EMBO J. 17: 7480-7489.

Jakob, U., M. Gaestal, K. Engel, and J. Buchner. 1993. Small heat shock proteins are molecular chaperons. J. Biol. Chem. 268: 1517-1520.

Lambert, H., S.J. Charette, A.F. Bernier, A. Guimond, and J. Landry. 1999. HSP27 multimerization mediated by phosphorylation-sensitive intermolecular interactions at the amino terminus. J. Biol. Chem. 274: 9378-9385.

Lamphear, B.J. and R. Panniers. 1990. Cap binding protein complex that restores protein synthesis in heat shocked Ehrlich cell lysates contains highly phosphorylated eIF-4E. I. Biol. Chem. 265: 5333-5336.

- 1991. Heat shock impairs the interaction of cap binding protein complex with $5^{\prime}$ mRNA cap. J. Biol. Chem. 266: 2789-2794.

Landry, J., P. Chretien, A. Laszlo, and H. Lambert. 1991. Phosphorylation of HSP27 during development and decay of thermotolerance in Chinese hamster cells. I. Cell. Physiol. 147: 93-101.

Laroia, G., R. Cuesta, and R.J. Schneider. 1999. Control of mRNA decay by the ubiquitinproteasome-heat shock network. Science 284: 499-502.

Li, L., G. Shen, and G.C. Li. 1995. Effects of expressing human Hsp70 and its deletion derivatives on heat killing and on RNA and protein synthesis. Exp. Cell. Res. 217: 460-468.

Lin, T.-A., X. Kong, T.A.J. Haystead, A. Pause, G. Belsham, N. Sonenberg, and J.C. Lawrence. 1994. PHAS-1 as a link between mitogen-activated protein kinase and translation initiation. Science 266: 653-656.

Liu, R.Y., X. Li, L. Li, and G.C. Li. 1992. Expression of human Hsp70 in rat fibroblasts enhances cell survival and facilitates recovery from translational and transcriptional inhibition following heat shock. Cancer Res. 52: 3667-3673.

Marissen, W.E. and R.E. Lloyd. 1998. Eukaryotic translation initiation factor $4 \mathrm{G}$ is targeted for proteolytic cleavage by caspase 3 during inhibition of translation in apoptotic cells. Mol. Cell. Biol. 18: 7565-7574.

Mizzen, L.A. and W.J. Welch. 1988. Characterization of the thermotolerant cell. I. Effects on protein synthesis activity and the regulation of heat-shock protein 70 expression. $J$. Cell. Biol. 106: 1105-1116. 
Cuesta et al.

Morimoto, R.I. 1998. Regulation of the heat shock transcriptional response: Cross talk between a family of heat shock factors, molecular chaperones, and negative regulators. Genes \& Dev. 12: 3788-3796.

New, L., Y. Jiang, M. Zhao, K. Liu, W. Zhu, L.J. Flood, Y. Kato, G.C. Parry, and J. Han. 1998. PRAK, a novel protein kinase regulated by the p38 MAP kinase. EMBO J. 17: 3372-3384.

Parsell, D.A. and S. Lindquist. 1993. The function of heat shock proteins in stress tolerance: Degradation and reactivation of damaged proteins. Annu. Rev. Genet. 27: 437-496.

Pause, A., G.J. Belsham, A.-C. Gingras, O. Donze, T.-A. Lin, J.C. Lawrence, and N. Sonenberg. 1994. Insulin-dependent stimulation of protein synthesis by phosphorylation of a regulator of 5'-cap function. Nature 371: 762-767.

Pyronnet, S., H. Imataka, A.C. Gingras, R. Fukunaga, T. Hunter, and N. Sonenberg. 1999. Human eukaryotic translation initiation factor 4G (eIF4G) recruits Mnk1 to phosphorylate eIF4E. EMBO J. 18: 270-279.

Rogalla, T., M. Ehrnsperger, X. Preville, A. Kotlyarov, G. Lutsch, C. Ducasse, C. Paul, M. Wieske, A.P. Arrigo, J. Buchner, and M. Gaestel. 1999. Regulation of Hsp27 oligomerization, chaperone function, and protective activity against oxidative stress/tumor necrosis factor alpha by phosphorylation. J. Biol. Chem. 274: 18947-18956.

Schneider, R.J. 2000. Translational control during heat shock. In Translational control (ed. J.W.B. Hershey, M. Mathews, and N. Sonenberg) Cold Spring Harbor Laboratory Press, Cold Spring Harbor, NY. (In press.)

Smith, D.B. and K.S. Johnson. 1988. Single-step purification of polypeptides expressed in Escherichia coli as fusions with glutathione S-transferase. Gene 67: 31-40.

Sonenberg, N. 1996. mRNA 5' cap-binding protein eIF-4E and control of cell growth. In Translational Control (ed. J.W.B. Hershey, M. Mathews, and N. Sonenberg), pp. 245-270. Cold Spring Harbor Laboratory Press, Cold Spring Harbor, NY.

Vries, R.G., A. Flynn, J.C. Patel, X. Wang, R.M. Denton, and C.G. Proud. 1997. Heat shock increases the association of binding protein-1 with initiation factor 4E. J. Biol. Chem. 272: $32779-32784$.

Wang, X., A. Flynn, A.J. Waskiewicz, B.L.J. Webb, R.G. Vries, I.A. Baines, J.A. Cooper, and C.G. Proud. 1998. The phosphorylation of eukaryotic initiation factor eIF-4E in response to phorbol esters, cell stresses and cytokines is mediated by distinct MAP kinase pathways. J. Biol. Chem. 273: 9373 9377.

Waskiewicz, A.J., A. Flynn, C.G. Proud, and J.A. Cooper. 1997. Mitogen-activated protein kinases activate the serine/threonine kinases Mnk1 and Mnk2. EMBO J. 16: 1909-1920.

Waskiewicz, A.J., J.C. Johnson, B. Penn, M. Mahalingham, S.R. Kimball, and J.A. Cooper. 1999. Phosphorylation of the capbinding protein eukaryotic translation initiation factor 4E by protein kinase Mnk1 in vivo. Mol. Cell. Biol. 19: 1871-1880.

Yueh, A. and R.J. Schneider. 1996. Selective translation by ribosome jumping in adenovirus infected and heat shocked cells. Genes \& Dev. 10: 1557-1567.

2000.Translation by ribosome shunting on adenovirus and Hsp70 mRNAs facilitated by complementarity to $18 \mathrm{~S}$ rRNA. Genes \& Dev. 14: 414-421.

Zapata, J.M., F.G. Maroto, and J.M. Sierra. 1991. Inactivation of mRNA cap-binding protein complex in Drosophila melanogaster embryos under heat shock. J. Biol. Chem. 266: 1600716014. 


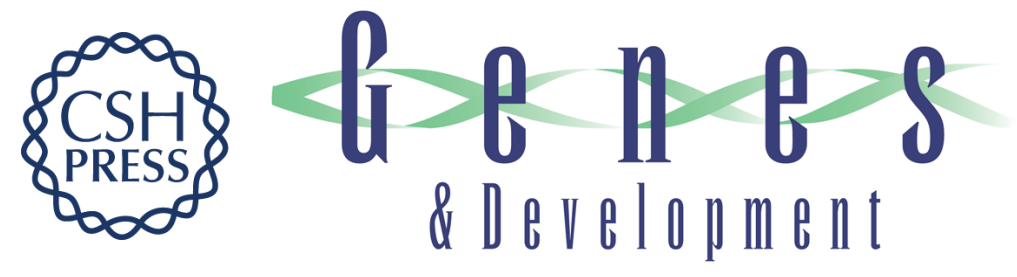

\section{Chaperone Hsp27 inhibits translation during heat shock by binding elF4G and facilitating dissociation of cap-initiation complexes}

Rafael Cuesta, Gaurav Laroia and Robert J. Schneider

Genes Dev. 2000, 14:

Access the most recent version at doi:10.1101/gad.14.12.1460

References

This article cites 40 articles, 29 of which can be accessed free at: http://genesdev.cshlp.org/content/14/12/1460.full.html\#ref-list-1

License

Email Alerting

Receive free email alerts when new articles cite this article - sign up in the box at the top Service right corner of the article or click here.

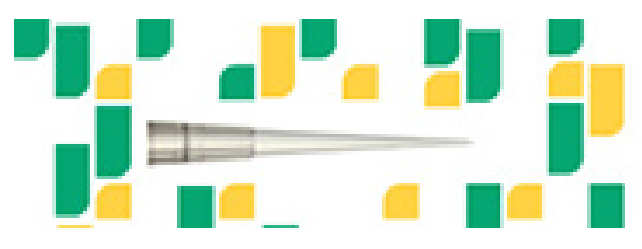

Focused on your science. 